\title{
"Mewah menuju Rahmatullah" : Pengaruh Status Sosial Ekonomi terhadap Persepsi Masyarakat Mengenai Trend Pemakaman Mewah Masyarakat Muslim
}

\author{
Masni Erika Firmiana, Siti Rahmawati, Rochimah Imawati \\ Program Studi Psikologi, Fakultas Psikologi dan Pendidikan \\ Universitas Al Azhar Indonesia, Jl. Sisingamangaraja, Jakarta 12110 \\ Penulis untuk korespondensi/E-mail: masni.erika@uai.ac.id
}

\begin{abstract}
Abstrak - Riset ini dilakukan untuk melihat pengaruh Status Sosial Ekonomi (SSE) yang terdiri dari pendidikan, pekerjaan, dan pendapatan terhadap persepsi mengenai trend pemakaman mewah di DKI Jakarta dan sekitarnya. Dengan harga 17 juta - milyaran rupiah per lubang makam (tergantung pengembang/ developer), ternyata peminatnya tidak sedikit, bahkan belakangan muncul pemakaman mewah khusus muslim. Padahal Islam sendiri menganjurkan umatnya untuk hidup dalam kesederhanaan. Teori yang akan digunakan dalam riset ini adalah Persepsi dan Status Sosial Ekonomi. Penelitian ini menggunakan teknik kuantitatif, pengumpul data utama adalah kuesioner, dan didukung oleh wawancara. Dengan jumlah responden 63 orang, hasil analisis data dengan regresi berganda menunjukkan Status Sosial Ekonomi berpengaruh sangat signifikan terhadap persepsi responden mengenai trend pemakaman mewah, sebesar $49 \%$. Faktor yang paling berpengaruh adalah pekerjaan. Saran penelitian selanjutnya adalah menggunakan Teori Reasoned Action dari Aczjen, untuk melihat intensi (kecenderungan bertingkah laku) melakukan pembelian makam mewah.
\end{abstract}

\section{Kata Kunci - Persepsi, Status Sosial Ekonomi, Pemakaman Mewah}

Abstract. - This research is conducted to analyze the effect of socioeconomic status to perceptions about lavish funeral's trends at DKI Jakarta and surroundings. For the minimum price 17 million - billions rupiahs (depends on developer), there is a lot of person who interested to having the lavish funeral. For a couple years ago, there is emerging lavish funeral for moslem, whereas Islam suggesting Moslems to unpretentious live. The theory in this research is perception, and socio economic status. This research using quantitative technique, the prime data collection is questionaire, and interview too. With $\mathrm{N}=63$, the data analyzed showed that there is a significant effect of socioeconomic status to perceptions about lavish funeral's, about $49 \%$. The most affected factor is occupation. The researcher suggesting the next research using The Reasoned Action Theory from Aczjen to asses the intention to buy lavish funeral.

Keywords - Perception, socioeconomic status, lavish funeral

\section{PENDAHULUAN}

$\mathrm{J}$ akarta, sebagai Ibukota negara, dan kota terbesar di Indonesia, saat ini sudah menanggung beban masalah kependudukan yang relatif sangat tinggi. Jumlah penduduk yang sangat besar, berimbas pada masalah lain seperti penyediaan fasilitas kesehatan, juga pemakaman. Saat ini tarif resmi penyelenggaraan pemakaman di TPU tak lebih dari Rp. 200.000 (dua ratus ribu rupiah), namun fakta di lapangan, biaya itu justru sangat membengkak, karena pungli yang dilakukan oleh sejumlah oknum
[1], [2]. Hal tersebut membuat rakyat kecil terbebani. Ironisnya, dalam beberapa tahun terakhir muncul trend pemakaman mewah dengan harga yang sangat tinggi, dan hanya mungkin dijangkau oleh warga yang sangat berkecukupan dalam hal ekonomi. Dengan harga paling murah (paket 10 orang) Rp.17.000.000 hingga Rp. 180.000.000/orang [3], [4] ), tentunya bukan nilai yang sedikit, mengingat Upah Minimum Regional (UMP) DKI 2014 sebesar Rp 2.200.000,- (kurang dari 1/10 harga makam), dan pendapatan per kapita 
Indonesia yang hanya US\$3.716 atau sekitar Rp 2.787.000/bulan [5], [6], [7].

Harga tinggi dari kompleks makam ini seimbang dengan layanan yang diberikan. Kompleks pemakaman mahal dan mewah ini dibangun dengan indah, sehingga menghindari kesan seram yang selama ini melekat pada kompleks pemakaman [8]. Harga yang mahal sebanding berbagai macam fasilitas dan layanan berkelas disediakan oleh pengelola, seperti rumah ibadah yang bagus dan megah, hotel, restoran Italia, kolam renang, dan danau buatan. Selain itu juga lokasi yang berbukit dan hijau, sangat menyenangkan untuk berjalan kaki, joging (tersedia jogging track), dan bersepeda. Karena tempat yang indah dan jauh dari kesan seram, tak jarang lokasi pemakaman mewah ini juga digunakan untuk pemotretan foto pre wedding.

Keistimewaan yang lain adalah pengelola menawarkan hanya membayar sekali seumur hidup (artinya setelah melunasi semua pembayaran maka pelanggan digratiskan dari biaya perawatan selamanya, sehingga tidak ada beban untuk ahli waris), juga lokasi makam yang bagus dan boleh dipilih (disesuaikan dengan dana yang dimiliki oleh calon pembeli). Pemilihan lokasi ini misalnya bagi etnis Tionghoa, yang memiliki kepercayaan bahwa semakin tinggi lokasi makam (ke arah perbukitan) semakin menunjukkan status sosial, berarti semakin bagus. Konsekuensinya adalah harga akan semakin mahal.

Pengelola juga memberikan layanan penyelenggaraan jenazah sesuai dengan agama yang dianut. Misalnya untuk yang Muslim, disediakan layanan mulai dari mengurus sejak diketahui meninggal, memandikan, mengafani, menyalatkan, sampai seremonial di tempat pemakaman (pengelola menyediakan ustadz, dan pembaca doa). Untuk pelanggan selain muslim, yang memilih nantinya ingin dikremasi, telah disediakan berbagai pilihan guci ataupun kotak tempat abu kremasi. Selanjutnya, tempat peletakan guci atau kotak juga dipilih sendiri, sesuai dengan dana yang dimiliki.

Pilihan cara pembelian kavling makam pun disediakan oleh pengelola. Ada yang bisa dipersiapkan sebelumnya oleh pelanggan semasa hidup, sehingga saat meninggal nanti tidak merepotkan pihak keluarga karena segala sesuatunya sudah diurus oleh pihak pengelola. Namun ada juga kavling makam yang baru dibeli oleh keluarga ketika ada anggotanya yang meninggal. Layanan penyelenggaraan jenazah yang diberikan oleh pengelola tetap sama, kecuali pihak keluarga menginginkan mengurus sendiri

Jika dilihat dari layanan maksimal yang disediakan, pemilihan makam yang mahal dan mewah untuk menuju Rahmatullah menunjukkan bahwa yang empunya kemungkinan besar memiliki dana yang cukup (bahkan sangat) besar. Islam sendiri hanya mewajibkan beberapa hal penting dalam penyelenggaraan jenazah : memandikan, mengafani, menyalatkan dan menguburkan, dan tidak ada ketentuan pemakaman dan tempat pemakaman yang berbiaya tinggi. Apalagi, dalam ketentuan syari'ah Islam, salah satu hak jenazah adalah dikuburkan. Hal tersebut menjadi kewajiban orang Islam yang masih hidup, sementara biayanya bisa berasal dari harta si mayyit ataupun dari baitul maal. Jadi tidak ada kewajiban si jenazah mempersiapkan pemakaman untuk dirinya sendiri; dan pada prinsipnya Islam tidak memiliki ajaran untuk hidup berlebih-lebihan.

Islam memandang kembalinya manusia kepada Yang Maha Kuasa sebagai sesuatu yang sangat individual, dan tidak berkaitan dengan hal-hal yang bersifat material. Allah SWT tidak akan melihat makhlukNya berdasar kekayaan atau hal-hal yang berkaitan dengan materi, tetapi hal yang berkaitan dengan ketaatan kepadaNya.

Memilih makam yang mewah dan mahal menunjukkan kemampuan seseorang / satu keluarga dalam bidang ekonomi. Hal ini juga menunjukkan individu ini memiliki posisi tertentu secara ekonomi di dalam masyarakatnya. Posisi dan strata ini akan merujuk kepada sejumlah materi dan privillege yang dimiliki. Status sosial adalah istilah yang digunakan untuk menjelaskan posisi/kedudukan seseorang dalam masyarakatnya. Status sosial dapat muncul dalam suatu masyarakat jika ada sesuatu hal yang dianggap/ dipersepsikan penting oleh warga masyarakat tersebut [9]. Barang siapa yang mampu memiliki sesuatu/barang yang dianggap berharga tersebut apalagi dalam jumlah yang banyak, maka akan dianggap/dipersepsikan oleh warga masyarakat yang lain sebagai individu yang menempati posisi atas, dan sebaliknya.

Bangsa Indonesia merupakan suatu bangsa dengan penduduk muslim terbesar, dan pendapatan per kapitanya masih rendah. Keputusan sebagian anggota masyarakat Muslim untuk membeli pemakaman mewah dan mahal untuk bertemu 
dengan Sang Pencipta seolah bertolak belakang dengan kesederhanaan yang disampaikan oleh Islam. Dengan demikian, yang menjadi pertanyaan penelitian ini adalah seperti apa persepsi masyarakat tentang pemakaman mewah dan mahal? Bagaimana kaitannya dengan SSE? Apakah SSE berpengaruh terhadap persepsi tersebut?

\section{KERANGKA TEORI}

\section{Persepsi}

Dalam Psikologi, persepsi selalu dikaitkan dengan sensasi. Sensasi adalah proses menerima energi rangsangan (energi fisik seperti cahaya, suara, dan panas) dari lingkungan luar, melalui indra. Ketika rangsangan ini sampai ke otak, otak akan memberikan makna terhadap sensasi tersebut melalui persepsi. Secara umum, persepsi adalah proses dengan mana individu mengorganisir dan menafsirkan kesan indrawi dari lingkungan. Tafsir atau arti suatu objek atau suatu kejadian objektif ditentukan oleh kondisi stimulan maupun oleh faktor individu itu sendiri. Dengan begitu, persepsi mengenai dunia akan berbeda pada tiap pribadi, karena setiap individu akan menanggapinya berkaitan dengan aspek situasi yang mengandung arti khusus bagi dirinya [10], [11], [12] , [13] [14], [15] Persepsi yang dilakukan manusia bertujuan untuk perwakilan internal dari dunia luar di sekitar manusia [10] Contohnya, tujuan penglihatan adalah membentuk perwakilan tiga dimensi dari dunia di otak. Dalam riset ini, tujuan persepsi adalah membentuk pendapat mengenai pemakaman mewah.

Proses terjadinya persepsi cukup panjang namun King [10], menyebutkan bahwa para psikolog membedakan proses persepsi pada dua hal : proses dari bawah ke atas; dan dan dari atas ke bawah. Pada proses dari bawah ke atas (bottom up proccessing), reseptor sensoris mencatat informasi mengenai lingkungan luar dan mengirimkannya ke otak untuk analisis dan interpretasi. Proses ini dipicu oleh masukan rangsangan [10] Ini berarti, manusia mengambil informasi dari lingkungan, dan mencoba memahaminya. Misal, ketika pertama kali mendengar sebuah lagu, manusia harus mendengar dengan baik untuk dapat "merasakan" lagu tersebut. Sebaliknya dengan pemrosesan dari atas ke bawah (top-bottom proccessing) yang dipicu oleh pemrosesan kognisi pada tingkat yang lebih tinggi pada otak [10]. Pemrosesan ini adalah ketika manusia merasakan apa yang sedang terjadi dan mengaplikasikan kerangka kerja tersebut pada informasi dari dunia luar. Proses kognitif itu antara lain pengetahuan, sistem kepercayaan dan keyakinan, juga harapan. Berdasar hal tersebut dapat dijelaskan bahwa proses persepsi dalam riset ini adalah pemrosesan dari atas ke bawah. Persepsinya adalah saat manusia merasakan apa yang sedang terjadi (adanya makam mewah), lalu mengaplikasikan kerangka pikir tersebut berdasar aspek seperti pengetahuan, dan harapan tentang pemakaman dalam Islam, dan pemakaman mewah.

Ada sejumlah faktor yang dapat berpengaruh pada persepsi seorang manusia, dan tidak sedikit teoritisi yang menyampaikan pendapatnya terkait ini. Namun menurut Robbin [12] ada beberapa faktor yang mempengaruhi persepsi yaitu :

1. Faktor yang berada dalam diri yang mempersepsi ( perceiver) berupa attitude, motive, interest, experience, dan expectation.

2. Faktor yang berada dalam objek yang dipersepsikan ( target ), berupa novelty, motion, sound, size, background dan proximity.

3. Faktor yang berada dalam situasi (situation), berupa bentuk, work setting dan social setting.

Dalam riset ini, yang akan menjadi kajian adalah manusia yang melakukan persepsi (perceiver). Berkaitan dengan fokus penelitian ini tentang persepsi individu/masyarakat terhadap suatu objek, maka faktor-faktor yang terdapat dalam diri pemersepsi (perceiver) adalah sebagai berikut [12] :

1. Sikap (attitude), diartikan sebagai pernyataan evaluatif, yang dapat dipengaruhi oleh nilai yang dianut seseorang terhadap suatu objek yang dapat mempengaruhi persepsi.

2. Motif (motive), sebagai suatu keinginan atau kebutuhan seseorang.

3. Interest, sesuatu yang sangat diperhatikan seseorang. Interest seseorang dapat dipengaruhi oleh pengalaman atau latar belakang orang tersebut.

4. Experience, pengalaman, yang dapat memengaruhi salah satu dari objek atau peristiwa. yang sangat diperhatikan oleh seseorang.

5. Expectation, harapan-harapan (pengharapan) seseorang terhadap sesuatu yang dapat sesuatu yang dapat mempengaruhi persepsi. Dalam riset ini, yang dimaksud dengan harapan adalah pengharapan seseorang terhadap pemakaman mewah. Jadi dalam riset ini, yang menjadi objek persepsi adalah pemakaman mewah. 


\section{Status, dan Status Sosial Ekonomi (SSE)}

Status merupakan bagian dari kajian tentang lapisan sosial atau stratifikasi sosial [9]; [16]; [17]. Status sosial adalah tempat seseorang secara umum dalam masyarakat sehubungan dengan orang lain, prestisenya, serta sejumlah hak dan kewajibannya. Status tidak hanya berarti kumpulan kedudukan seseorang dalam kelompok yang berbeda, tetapi status tersebut memengaruhi kedudukan orang tersebut di dalam kelompok-kelompok sosial yang berbeda, karena di dalamnya ada hak, kewajiban, dan privilese. Setiap orang memiliki kedudukan yang berbeda, tergantung dari dimana dia berada pada suatu waktu. Misalnya seorang laki-laki yang berstatus sebagai Kepala Sekolah di tempat bekerja, sebagai ayah jika berada di rumah, sebagai warga biasa di RT lingkungan tempat tinggal, dan sebagai bendahara di organisasi PGRI. Status sosial membuat seseorang berada pada posisi di atas, tengah, atau bawah di dalam masyarakatnya.

Strata sosial juga memiliki indikator yang berbeda, tergantung dari apa yang dianggap berharga oleh masyarakat tersebut. Jika yang dihargai adalah pendidikan, maka orang yang memiliki pendidikan paling tinggi dianggap menduduki posisi tertinggi, dan sebaliknya. Jika yang dihargai adalah pekerjaan, maka bekerja/tidak bekerja menjadi indikator status seseorang; atau, bisa termasuk juga di dalamnya jenis pekerjaan yang dilakukan. Jika yang dihargai adalah materi, maka orang yang memiliki materi sangat banyak akan menduduki lapisan paling atas, dan sebaliknya. Keterbatasan sumber daya tidak menjadi halangan bagi orang yang memiliki limpahan materi, karena dengan memiliki limpahan materi, seseorang mampu membeli apapun yang orang lain tidak sanggup, seperti pemakaman yang mahal.

Sementara itu, status sosial ekonomi (selanjutnya akan disingkat dengan SSE) adalah gambaran tentang posisi seseorang atau suatu masyarakat yang ditinjau dari segi sosial ekonomi. Gambaran itu seperti tingkat pendidikan, pendapatan dan sebagainya. Soekanto [9], menyatakan bahwa status sosial ekonomi seseorang dapat diukur dari:

1. Kekayaan, yang berupa harta benda atau materi yang dimiliki oleh seseorang. Ukuran kekayaan tersebut dapat dilihat dari bentuk dan luas rumah yang bersangkutan, luas kepemilikan tanah, kepemilikan barang berharga dan fasilitas yang dimiliki.

2. Kekuasaan merupakan wewenang atau kewenangan seseorang yang dimiliki oleh seseorang karena kedudukannya dalam masyarakat, lembaga atau suatu perusahaan yang dipimpinnya.

3. Kehormatan, merupakan kewibawaan yang dimiliki oleh seseorang karena pembawaan atau kedudukan atau hal yang dianggap oleh orang lain sebagi suatu yang terpandang. Biasanya mereka adalah golongan tua atau mereka yang pernah berjasa pada masyarakat.

4. Ilmu Pengetahuan, merupakan sesuatu yang diperoleh seseorang melalui proses belajar dalam suatu pendidikan baik pendidikan formal, non formal, informal.

Berdasarkan pendapat tersebut, maka terkait dengan tujuan riset ini, ukuran yang digunakan untuk melihat status sosial ekonomi seseorang adalah pendidikan, pekerjaan, dan pendapatan. Seperti yang disampaikan oleh Soekanto [9], bahwa faktor-faktor status sosial ekonomi ini tidak dapat dipisahkan satu sama lain. Dapat dijelaskan disini bahwa jika seorang individu memiliki pendidikan yang baik (pendidikan tinggi), biasanya memiliki intelektual yang lebih baik, mampu berpikir kritis dibanding yang tidak memiliki pendidikan tinggi sehingga mampu membantu untuk meningkatkan kualitas hidupnya. Lebih jauh, individu ini juga akan beroleh pekerjaan yang baik (pekerjaan yang berada di lapisan atas). Selanjutnya, dengan pekerjaan yang baik tersebut, maka individu akan memiliki pendapatan yang juga baik, sehingga dia dapat masuk ke kelompok status sosial ekonomi yang tinggi.

Lebih jauh, status sosial ekonomi dapat dijabarkan sebagai berikut (Yulisanti, [18] ; dalam Lestarini, [19]):

1. Pendidikan.

Tinggi rendahnya pendidikan akan memengaruhi jenjang status sosial seseorang, karena pendidikan bukan sekadar memberikan perubahan cara pandang, cara pikir, keterampilan kerja, tetapi juga mengubah selera, minat, etiket dan cara bicara seseorang. Berdasar penjelasan tersebut, dapat ditegaskan bahwa aspek pendidikan turut berperan dalam pembentukan, minat, selera, etiket, sikap, serta cara bicara seseorang. Pada riset ini, akan diteliti mengenai pengaruh tinggi rendahnya jenjang pendidikan terhadap aspekaspek persepsi seperti minat, motif, juga harapan responden terhadap pemakaman mewah. Dalam riset ini, pembagian tingkatan pendidikan akan dilihat dari :

a. Rendah : Lulus SD

b. Menengah : lulus SMA

c. Tinggi : lulus Sarjana 
2. Pekerjaan / Jabatan

Di bidang pekerjaan, ada beberapa jenis pekerjaan tertentu yang dapat membuat seseorang menjadi lebih terhormat dibanding orang lainnya. Pekerjaan yang dimaksud akan sangat berkaitan erat dengan jabatan/posisi seseorang dalam lingkungan kerjanya. Jabatan merupakan sekelompok posisi yang mengandung persamaan dalam kewajiban, kecakapan (keterampilan), pengetahuan (berkait dengan pendidikan), dan tanggung jawab. Untuk aspek pekerjaan akan diklasifikasikan sebagai berikut [19] :

a. Pekerjaan yang berstatus tinggi, yaitu tenaga ahli, profesi (misal dokter, pengacara, guru/dosen, perawat), pemimpin ketatalaksanaan dalam suatu instansi baik pemerintah maupun swasta, tenaga administrasi, tata usaha.

b. Pekerjaan yang berstatus menengah, yaitu pekerjaan di bidang penjualan dan jasa.

c. Pekerjaan yang berstatus rendah, yaitu petani, buruh, dan operator alat angkut/bengkel.

Pada riset ini, akan diteliti pengaruh tinggi rendahnya status pekerjaan seseorang pada persepsinya terhadap pemakaman mewah.

\section{Penghasilan}

Jika suatu pekerjaan membutuhkan pendidikan, keahlian dan keterampilan khusus / tinggi maka biasanya akan memberikan penghasilan yang juga tinggi. Pekerjaan yang berada pada level teknis seperti operator, cenderung tidak membutuhkan pendidikan dan keahlian yang khusus, sehingga penghasilannya juga tidak tinggi. Di dalam penelitian ini, kategori tinggi rendahnya penghasilan seseorang dilihat berdasarkan UMP DKI Jakarta yaitu sebesar 2,2 Juta ( [20] dan [6] ). Terkait penelitian ini, berdasarkan klasifikasi dari Biro Pusat Statistik ( [21] 2008, dalam [22] Halifat, 2014) maka strata untuk penghasilan disusun sebagai berikut :

a Golongan pendapatan sangat tinggi adalah jika pendapatan rata-rata lebih dari Rp. 3.500.000,00 per bulan

b Golongan pendapatan tinggi adalah jika pendapatan rata-rata antara Rp. $2.500 .000,00 \mathrm{~s} / \mathrm{d}$ Rp. 3.500.000,00 per bulan

c Golongan pendapatan sedang adalah jika pendapatan rata-rata dibawah antara Rp. 1.500 .000 s/d Rp. 2.500.000,00 per bulan 13

d Golongan pendapatan rendah adalah jika pendapatan rata-rata Rp. $1.500 .000,00$ per bulan kebawah.

Mengingat aspek pendidikan, dan pekerjaan hanya terdiri dari 3 (tiga) strata, maka untuk menyeimbangkannya, peneliti membagi strata untuk pendapatan menjadi tiga, dengan mengambil UMP sebagai patokan terendah, dan kemungkinan minimum pembayaran cicilan pemakaman mewah :

a. Rendah : < Rp. 2.200 .000

b. Menengah : Rp 2.300.000 - Rp. 5.000 .000

c. Tinggi > Rp. 5.000.000,

Berdasarkan pembahasan sebelumnya tentang pendidikan, pekerjaan, dan pendapatan, jika dibuatkan matriks, maka strata dan status sosial ekonomi akan terlihat seperti Tabel 1 di lampiran.

\section{Pemakaman dalam Pandangan Islam}

Kata "makam" berarti "kuburan". Kata "kuburan" berasal dari kata dasar "kubur", berasal dari bahasa Arab, yang berarti memendam, memasukkan, melupakan, mengebumikan. Kata "makam" juga berarti tempat, tempat tinggal, dan kediaman. "Kubur", dari bahasa Arab adalah kata kerja (verba) yang berarti menanam atau memendam sesuatu, biasanya jenazah seseorang atau bangkai hewan di dalam tanah. Kuburan atau pekuburan adalah tempat di mana jenazah-jenazah dikubur. Kuburan, atau pekuburan, juga disebut pemakaman [23].

Menguburkan jenazah hukumnya wajib kifayah meskipun jenazahnya non muslim, sebagaimana telah dicontohkan oleh Rasulullah SAW. Penguburan jenazah manusia juga dilakukan untuk menghormati dan menghargai si jenazah, juga membedakannya dengan bangkai hewan. Para ahli fiqih juga telah sepakat bahwa memakamkan atau menguburkan jenazah hukumnya adalah fardu kifayah sebagaimana halnya memandikan, mengafani, dan mensalatkan. Kewajiban menguburkan ini ditetapkan berdasarkan Al-qur'an Surat Al-Mursalat ayat 25-26, yang artinya: "Bukankah Kami menjadikan bumi (tempat) berkumpul, orang- orang hidup dan orang-orang mati" (Q.S. Al-Mursalat : 25-26). Selain itu, dalam Surat Abasa ayat 21 dinyatakan: "Kemudian Dia mematikannya dan memasukannya ke dalam kubur" (Q.S. Abasa : 21).

Cara memakamkan manusia berawal dari kisah anak-anak Nabi Adam AS seperti yang tercantum dalam Surat Al Maidah 27-31. Ketika Qabil membunuh Habil, Allah menyuruh seekor burung gagak menggali-gali di bumi untuk memperlihatkan kepada Qabil bagaimana dia harus menguburkan mayat saudaranya. Namun setelah Islam datang, terdapat sejumlah ketentuan yang harus dilakukan oleh manusia yang masih hidup terhadap 
saudaranya yang meninggal : memandikan, mengafani, mensalatkan, dan menguburkan mayat. Mengenai kegiatan menguburkan ini, seperti yang tercantum dalam Al Quran, Surat Almursalat ayat 25-26, yang menjelaskan bahwa Allah telah menyediakan bumi sebagai tempat untuk menguburkan/memakamkan. Sedangkan mengenai tempat yang akan digunakan untuk menguburkan, dalam hukum fiqh islam dikenal berbagai sebutan /cara untuk memperolehnya. Cara tersebut adalah : jual beli, tukar-menukar, infak, sedekah, hadiah, wasiat, wakaf, warisan, hibah, zakat, dan ihyaul mawat [23]. Dalam riset ini, pemakaman yang dimaksud adalah yang diperoleh dengan jual beli, dengan harga yang relatif mahal jika dibandingkan dengan UMP DKI Jakarta sendiri.

\section{Pemakaman Mewah menurut MUI}

MUI telah membahas pemakaman mewah dalam pandangan Islam dan mengeluarkan fatwa nomor 09 Tahun 2014, pada 20 Februari 2014 M [24] . Di dalam fatwa tersebut MUI antara lain memutuskan bahwa jual beli dan bisnis lahan untuk kepentingan kuburan mewah yang terdapat unsur tabdzir dan israf hukumnya haram. Tabdzir sendiri adalah menggunakan harta untuk sesuatu yang sia-sia dan tidak bermanfaat menurut ketentuan syar'i ataupun kebiasan umum di masyarakat; sedangkan Israf adalah tindakan yang berlebih-lebihan, yaitu penggunaan lahan melebihi kebutuhan pemakaman. Sedangkan Kuburan Mewah dinyatakan sebagai kuburan yang mengandung unsur tabdzir dan israf, baik dari segi luas, harga, fasilitas, maupun nilai bangunan.

Keputusan MUI tersebut didasari oleh Firman ALLAH SWT, Hadist Rasulullah SAW, dan Qaidah ushuliyyah dan qaidah fiqhiyyah.

Firman Allah SWT yang menegaskan kesederhanaan dalam hidup antara lain : "Dan orang-orang yang baik adalah apabila menyalurkan (hartanya) maka ia tidak berlebihlebihan dan tidak terlalu pelit. Dan adalah di antara kedua itulah yang baik." (QS : al Furqan[ 25]:76).

Firman Allah SWT juga melarang perbuatan tabdzir dan israf (melampaui batas) serta perbuatan sia-sia :

"Dan janganlah kamu menghamburkan (hartamu). Sesungguhnya para penghambur harta itu adalah saudara-saudara syaitan, sedangkan syaitan itu adalah sangat ingkar kepada Tuhannya. (QS. AlIsra' [17]: $26-27$ )
“... Dan janganlah kamu berlebih-lebihan. Sesungguhnya Allah tidak menyukai orang-orang yang berlebih-lebihan. (QS: al-An'am [6]: 141)

Hal lain yang ikut mendasari adalah hadist Rasulullah SAW :

Adanya pembolehan menyiapkan kain kafan untuk persiapan pada saat meninggal. Dengan demikian, maka dibolehkan juga menyiapkan kavling untuk kuburan; namun ada pelarangan untuk hal lain, semisal menambah lapisan pada kuburan.

"Dari Jabir, berkata: Rasulullah SAW melarang kuburan itu dilapisi kapur, diduduki, dan dipasang atap di atasnya". (HR. Muslim);

"Dari Jabir, berkata: Rasulullah SAW. melarang kuburan itu dilapisi kapur, dipasang tulisan, dipasang atap di atasnya, dan diinjak". (HR. Tirmidzi);

Dari Jabi ra ia berkata: Rasulullah SAW melarang kuburan itu dipasang atap di atasnya, atau ditambah tanah, atau dilapisi kapur". Sulaiman ibn Musa menambahkan redaksi "atau memasang tulisan di atasnya" (HR. Al-Nasai).

Selain itu ada Qaidah ushuliyyah dan qaidah fiqhiyyah yang mendasari, yaitu

"Pada prinsipnya setiap hal (di luar ibadah) adalah boleh kecuali ada dalil yang menunjukkan sebaliknya"

"Pada dasarnya, semua bentuk muamalah boleh dilakukan kecuali ada dalil yang mengharamkannya."

"Kebijakan imam (pemerintah) terhadap rakyatnya didasarkan pada kemaslahatan."

"Sesuatu kewajiban yang hanya bisa terlaksana dengan adanya suatu perbuatan (sarana), maka perbuatan (yang menjadi sarana) tersebut hukumnya (juga) wajib"

"Segala mudharat (bahaya) harus dihindarkan sedapat mungkin"

Ada sejumlah hal yang juga jadi bahan pertimbangan MUI [24] yaitu Imam an-Nawawi dalam kitab Raudlatu al-Thalibin, Juz I halaman 623 [24], menerangkan soal penggunaan jenis kafan sesuai dengan kondisi si mayyit, tetapi tidak boleh berlebih-lebihan. Dari sini bisa dipahami pada masalah kuburan : "Yang dianggap dalam penggunaan kain kafan yang dibolehkan bagi mayyit adalah kondisi keadaan mayyit. Jika ia 
termasuk orang kaya maka (kain kafannya) dari jenis pakaian yang paling bagus. Jika ia termasuk orang yang biasa maka dari jenis pakaian yang biasa. Dan jika ia termasuk orang miskin maka dari jenis pakaian yang sederhana. Mereka berkata: Dan dimakruhkan berlebih-lebihan dalam hal kain kafan".

Berdasarkan hal tersebut dapat dilihat, bahwa ada larangan untuk berlebih-lebihan, yang dalam hal ini dicontohkan dengan penggunaan kain kafan. Jika kita kaji lebih jauh, terkait kain kafan sudah ada ketentuan, apalagi dalam hal fasilitas pemakamannya.

Selanjutnya MUI menyatakan bahwa setiap orang muslim boleh menyiapkan lahan khusus sebagai tempat untuk dikuburkan saat ia meninggal, dan boleh berwasiat untuk dikuburkan di tempat tertentu sepanjang tidak menyulitkan. MUI juga menyebutkan dalam salah satu keputusannya bahwa jual beli lahan pemakaman dibolehkan selagi memenuhi ketentuan dalam syariat Islam, sesuai dengan hukum jual beli dalam Islam, serta dilakukan dengan prinsip sederhana, tidak mendorong adanya tabdzir, israf, dan perbuatan sia-sia yang membuat umat berpaling dari ajaran Islam.

Berdasarkan hal tersebut, MUI memberikan rekomendasinya, antara lain : Pelaku usaha yang bergerak di bidang jual beli tanah kavling untuk kuburan tidak menjual kemewahan dalam bisnisnya yang mendorong pada perilaku tabdzir, israf, serta perbuatan sia-sia; Masyarakat yang berkecukupan hendaknya mentasarrufkan hartanya untuk kepentingan yang bermanfaat sebagai bekal untuk kematian; Umat Islam diminta untuk tidak larut dalam perilaku tabdzir, israf, serta perbuatan sia-sia dengan membeli kavling pekuburan mewah.

\section{Kerangka Berpikir}

Berdasarkan pemaparan sebelumnya, maka dapat dijelaskan kerangka berpikir seperti yang tercantum dalam Gambar 1. Berdasar gambar tersebut, diasumsikan bahwa semakin tinggi SSE semakin positif persepsi terhadap pemakaman mewah, dan sebaliknya. Jika disusun, maka hipotesisnya adalah sebagai berikut:

a. Ho1 : tidak ada pengaruh antara SSE dengan persepsi responden terhadap pemakaman mewah

b. Ha1 : ada pengaruh antara SSE dengan persepsi responden terhadap pemakaman mewah c. Ho2 : tidak ada pengaruh antara aspek Pendidikan dengan persepsi responden terhadap pemakaman mewah

d. Ha2 : ada pengaruh antara aspek Pendidikan dengan persepsi responden terhadap pemakaman mewah

e. Ho3 : tidak ada pengaruh antara aspek pekerjaan dengan persepsi responden terhadap pemakaman mewah

f. Ha3 : pengaruh antara aspek pekerjaan dengan persepsi responden terhadap pemakaman mewah

g. Ho4 : tidak ada pengaruh antara aspek pendapatan dengan persepsi responden terhadap pemakaman mewah

h. Ha 4 : ada pengaruh antara aspek pendapatan dengan persepsi responden terhadap pemakaman mewah.

\section{METODE PENELITIAN}

\section{Teknik Penelitian}

Penelitian ini menggunakan teknik kuantitatif yang merupakan sebuah penelitian yang menggunakan sejumlah pengukuran numerik terkait fenomena yang sedang diteliti [25]. Pendekatan dalam penelitian ini adalah survey, yaitu penelitian yang mengambil sampel dari satu populasi dan menggunakan kuesioner sebagai alat pengumpulan data yang pokok dan mengumpulkan data mengenai faktor -faktor yang berkaitan dengan variabel penelitian [26].

\section{Variabel Penelitian}

Dalam riset ini terdapat dua variabel, yaitu variabel bebas (independent variable/IV), dan variabel terikat (dependent variable/DV). Variabel bebas dalam riset ini adalah status sosial ekonomi, dan variabel terikat adalah persepsi tentang pemakaman mewah. Variabel bebas terdiri dari 3 aspek yaitu pendidikan, pekerjaan dan pendapatan. Sedangkan viariabel terikat terdiri dari 5 faktor, yaitu sikap, motif, minat, pengalaman, dan harapan. Seperti yang sudah tercantum di bagian kerangka berpikir, bahwa dalam riset ini akan melakukan analisis pada pengaruh SSE terhadap persepsi mengenai pemakaman mewah

\section{Responden}

Meskipun riset ini adalah riset survey, namun peneliti tidak menghitung populasi. Penarikan sampel dilakukan secara accidental di tempattempat ibadah umat Islam, dan lembaga bernuansa Islam lainnya. Setelah melalui proses perkenalan dan pendekatan, kuesioner diserahkan kepada 
responden untuk diisi. Selain itu, pengumpulan data juga dilakukan dengan mengirimkan email ke sejumlah kenalan. Dari sekitar 50 (lima puluh) email yang dikirimkan, hanya kembali hanya 33 (tiga puluh tiga). Total responden dalam riset ini adalah 63 (enam puluh tiga) orang.

\section{Teknik dan Instrumen Pengumpulan Data}

Teknik pengumpulan data adalah dengan daftar pertanyaan dan wawancara, sedangkan alat pengumpul data utama adalah kuesioner/ skala. Pada umumnya kuesioner berisi keterangan tentang fakta yang diketahui oleh responden [27]. Kuesioner dibuat berdasarkan indikator-indikator dari konsep yang ada di dalam teori. Blue print alat ukur serta alat ukur yang sudah dibuat dapat dillihat di bagian lampiran (Tabel 2 dan Tabel 3 di lampiran). Sementara itu wawancara dilakukan secara acak pada responden yang selesai mengisi dan mengembalikan kuesioner. Hasil wawancara langsung dituliskan di lembar kuesioner.

\section{Metode Analisis Data}

Data mentah dari kuesioner diolah menggunakan regresi berganda. Selanjutnya hasil analisis tersebut akan dibaca dan dikaitkan dengan teori yang digunakan. Analisis juga didukung data lain yaitu wawancara dengan responden yang dipilih secara acak.

\section{TEMUAN DAN ANALISIS DATA}

\section{Gambaran Umum Responden Penelitian \\ Berdasarkan Usia}

Untuk menggambarkan responden penelitian berdasar usia, dapat dilihat pada Tabel 4 .

Tabel 4. Gambaran umum responden berdasar usia Sumber : data primer, 2014

\begin{tabular}{cccc}
\hline No. & Usia & f & \% \\
\hline 1 & $20-25$ & 17 & 27 \\
2 & $26-30$ & 23 & 37 \\
3 & $31-35$ & 11 & 17 \\
4 & $36-40$ & 10 & 16 \\
5 & $41-45$ & 2 & 3 \\
\hline \multicolumn{2}{r}{ JUMLAH } & 63 & 100 \\
\hline
\end{tabular}

Dari tingkat pengklasifikasian usia pengisi kuisioner, dapat dilihat bahwa kelompok usia terbesar pada responden penelitian ini adalah usia 26-30 (37\%) dan paling sedikit pada usia 41-45 tahun $(3 \%)$

\section{Berdasarkan Jenis Kelamin}

Jika dilihat berdasarkan jenis kelamin, responden dapat dikelompokkan seperti dalam Tabel 5.

Tabel 5. Gambaran umum responden berdasar jenis kelamin

Sumber : data primer 2014

\begin{tabular}{ccc}
\hline Jenis kelamin & $\mathrm{F}$ & $\%$ \\
\hline $\mathrm{L}$ & 36 & 57 \\
$\mathrm{P}$ & 27 & 43 \\
\hline & 63 & 100 \\
\hline
\end{tabular}

Pengelompokan responden berdasar jenis kelamin, responden terbanyak berjenis kelamin laki-laki $(57 \%)$

\section{Berdasarkan Pendidikan}

Pengelompokan berdasar jenjang pendidikan, menghasilkan tabel seperti Tabel 6. Dari tingkat pendidikan dapat dilihat dari tiga (3) tingkat klasifikasi yaitu rendah, menengah dan tinggi. Jumlah responden terbanyak berada di strata pendidikan tinggi 50 responden $(79 \%)$

Tabel 6. Gambaran umum responden berdasar tingkat pendidikan

Sumber : data primer 2014

\begin{tabular}{ccc}
\hline $\begin{array}{c}\text { Tingkat } \\
\text { pendidikan }\end{array}$ & $\mathbf{f}$ & $\boldsymbol{\%}$ \\
\hline SD (Rendah) & 2 & 1 \\
SMP dan SMA & 12 & 19 \\
$\begin{array}{c}\text { (Menengah) } \\
\text { Perguruan Tinggi } \\
\text { (Tinggi) }\end{array}$ & 50 & 79 \\
\hline & 63 & 100 \\
\hline
\end{tabular}

\section{Berdasarkan Tingkat Pekerjaan}

Berdasar tingkat pekerjaan, responden terbanyak pada tingkat pekerjaan yang tinggi sebanyak 48 responden $(76 \%)$ seperti yang tercantum di Tabel 7 di bawah ini.

Tabel 7. Gambaran umum responden berdasar tingkat pekerjaan

Sumber : data primer 2014

\begin{tabular}{ccc}
\hline Tingkat pekerjaan & $\mathrm{f}$ & $\%$ \\
\hline Rendah & 3 & 5 \\
Menengah & 12 & 19 \\
Tinggi & 48 & 76 \\
\hline & 63 & 100 \\
\hline
\end{tabular}




\section{Berdasarkan Tingkat Pendapatan}

Tabel 8. Gambaran umum responden berdasar tingkat pendapatan

Sumber : data primer 2014

\begin{tabular}{ccc}
\hline Tingkat pendapatan & $\mathrm{f}$ & $\%$ \\
\hline Rendah & 2 & 3 \\
Menengah & 33 & 52 \\
Tinggi & 28 & 45 \\
\hline & 63 & 100
\end{tabular}

Berdasar Tabel 8, terlihat bahwa jumlah responden terbanyak berada di tingkat pendapatan untuk menengah dengan kisaran pendapatan 2,3-5 juta sebanyak 33 responden atau $52 \%$,

\section{Berdasar Pengetahuan tentang Pemakaman Mewah}

Tabel 9. Gambaran umum responden berdasar Pengetahuan tentang Pemakaman Mewah Sumber : data primer 2014

\begin{tabular}{ccc}
\hline $\begin{array}{c}\text { Pernah } \\
\text { memperoleh } \\
\text { informasi tentang } \\
\text { pemakaman } \\
\text { mewah? }\end{array}$ & $\mathrm{f}$ & $\%$ \\
\hline Pernah & & \\
Tidak & 45 & 71 \\
& 18 & 29 \\
\hline & 63 & 100
\end{tabular}

Ketika responden dikelompokkan berdasar pengetahuan tentang pemakaman mewah, terdapat 45 orang responden (71\%) yang mengetahui tentang pemakaman mewah, sisanya 18 orang (29\%) tidak pernah mendengar tentang pemakaman mewah. Pertanyaan ini muncul sebagai informasi awal, supaya dapat dilanjutkan dengan pertanyaan berikutnya. Jika jawabannya adalah tidak pernah mendengar, tentu kita tidak dapat informasi tentang persepsinya mengenai pemakaman mewah, karena sesuai teori, persepsi dapat muncul berdasarkan sensasi dari alat indra, antara lain mendengar (indra pendengaran) dan membaca (indra penglihatan)

\section{Pengaruh SSE terhadap Persepsi mengenai Pemakaman Mewah}

Selanjutnya akan dilakukan analisis mengenai pengaruh variabel bebas (SSE) terhadap variabel terikat (persepsi mengenai pemakaman mewah), dengan teknik regresi berganda yaitu Tabel Summary R (Tabel 10, lihat lampiran di halaman terakhir), Tabel Summary R disebut juga dengan koefisien korelasi. Pada tabel ini dapat dibaca bahwa nilai koefisien korelasi antara variabel SSE (X) terhadap Persepsi (Y) adalah 0,491, berarti hubungan antara adalah variabel SSE (X) terhadap Persepsi (Y) adalah sangat kuat. Dapat dijelaskan, bahwa secara bersama-sama, pendidikan, pekerjaan, dan pendapatan memiliki hubungan yang sangat signifikan dengan persepsi terhadap pemakaman mewah. Faktor pendidikan, pekerjaan, dan pendapatan memiliki pengaruh sebesar $49,1 \%$ terhadap persepsi mengenai pemakaman mewah, dan sisanya dipengaruhi oleh faktor lain yang tidak diteliti dalam penelitian ini.

Pendidikan tidak dapat dipisahkan dengan pekerjaan dan pendapatan, karena 3 hal ini memang selalu saling terkait. Pendidikan yang baik tidak dapat dipisahkan dari adanya dana (pendapatan); sementara pendapatan yang lebih baik akan susah diperoleh jika pekerjaan yang dimiliki juga berada di strata yang rendah; status pekerjaan yang berada di strata bawah juga dipengaruhi oleh jenjang pendidikan yang rendah. Padahal, pendidikan akan membantu dan mengubah manusia menjadi berpikir kritis. Dengan pemikiran yang kritis, manusia mampu merasakan apa yang sedang terjadi di sekitar dirinya (misalnya trend pemakaman mewah), lalu mengaplikasikan kerangka pikir berdasar aspek pengetahuan, dan harapan tentang pemakaman mewah tersebut.

Selanjutnya, Berdasarkan Tabel 11 (lihat lampiran di halaman akhir), diketahui bahwa harga $F_{\text {hitung }}=$ 6.237, sedangkan harga $F_{\text {tabel }}$ pada taraf signifikan $(\alpha)=0,05$ dengan derajat kebebasan pembilang 1 , dan derajat kebebasan penyebut 59, yang menyatakan koefisien arah regresi tidak nyata (non signifikan) ditolak, dan kita menerima hipotesis yang menyatakan koefisien arah regresi nyata (sangat signifikan). Dengan perkataan lain koefisien arah regresi tidak sama dengan nol, oleh karena itu persamaan regresi yang diperoleh dapat digunakan untuk menjelaskan dan mengambil kesimpulan lebih lanjut mengenai hubungan antara SSE dengan Persepsi.

Berikut, pada tabel Koefisien regresi (Tabel 12, lihat lampiran) dapat terlihat signifikansi dari ketiga komponen SSE, yaitu : 
1. Faktor Pendidikan, memiliki signifikansi sebesar 0.977. Berdasarkan nilai signifikansi 0.977 $>0.05$, maka $\mathrm{Ha}_{2}$ ditolak, yaitu faktor pendidikan tidak memberi pengaruh yang signifikan pada persepsi mengenai pemakaman mewah. Hal ini menunjukkan bahwa tinggi rendahnya pendidikan tidak memiliki pengaruh signifikan terhadap persepsi responden mengenai pemakaman mewah. Lebih jauh, tinggi rendahnya pendidikan tidak memiliki pengaruh terhadap penilaian, motif (kebutuhan), minat, pengalaman dan pengharapan responden mengenai pemakaman mewah.

\section{Faktor pekerjaan.}

Berdasar analisis statistik, faktor memiliki signifikansi sebesar 0.001. Berdasarkan nilai signifikansi $0.001<0.05$, maka Ha3 diterima, artinya faktor pekerjaan memberikan pengaruh yang signifikan terhadap persepsi responden terhadap pemakaman mewah. Semakin tinggi status pekerjaan, akan semakin berpengaruh pada persepsinya mengenai pemakaman mewah. Berdasar analisis data, strata dalam hal pekerjaan menjadi lebih penting dibanding 2 (dua) faktor SSE lainnya. Pekerjaan yang terlihat lebih baik (berada di strata tinggi), meski tidak seimbang dengan pendapatan yang juga tinggi memiliki pengaruh pada minat, harapan, penilaian dari responden tentang pemakaman mewah.

Faktanya, ada sejumlah pekerjaan tertentu yang berada di strata tinggi, tetapi secara materi berada di strata menengah atau bawah namun dapat menguntungkan individu dari hal / sisi yang lain (misalnya memiliki kekuasaan dan kewenangan yang cukup luas, serta sejumlah simbol strata dan priviles lainnya). Salah satu contohnya adalah posisi sebagai Kepala Cabang Pemasaran sebuah perusahaan di kota $X$. Jika dilihat dari strata pekerjaan, posisi kepala cabang berada di level top management, namun tidak demikian jika dilihat dari sisi penghasilan (materi), karena bawahannya (tenaga pemasaran) dapat memiliki pendapatan hingga 5 (lima) kali lebih banyak. Meski demikian di sisi lain, ada simbol status yang dimiliki Kepala Cabang yaitu fasilitas kantor berupa kendaraan roda empat, penggantian uang bahan bakar dan tunjangan kesehatan yang lebih besar (yang tidak dimiliki oleh para bawahannya). Hal ini berpengaruh pada minat, harapan, penilaian responden tentang pemakaman mewah. tampaknya pemakaman mewah juga dianggap sebagai salah satu simbol status dari pekerjaan yang berada di strata tinggi.
Hal / contoh lain adalah individu merasa sudah memiliki simbol status yang baik di masyarakat, sehingga berharap akan dapat melengkapi dengan kepemilikan pemakaman mewah. Sementara jika dikaitkan dengan klasifikasi pekerjaan dalam SSE [19], pekerjaan seperti tenaga administrasi, dan tata usaha sebuah instansi, baik swasta maupun pemerintah termasuk strata tinggi. Jadi dalam pandangan masyarakat pekerjaan ini dianggap sebagai salah satu pekerjaan yang paling baik, dan memiliki prestise. Meski faktanya, dua pekerjaan ini termasuk pekerjaan yang secara finansial tidak memungkinkan memperoleh limpahan materi, sehingga secara ekonomi berada di strata bawah. Prestise inilah yang kemudian dapat membawa individu untuk tetap berharap memiliki simbol status berupa pemakaman mewah tersebut.

Anggapan bahwa pemakaman mewah merupakan penghargaan bagi almarhum, menunjukkan bahwa orang dengan posisi tertentu dalam hal pekerjaan, layak untuk memiliki pemakaman mewah, atau dimakamkan di pemakaman mewah. Alasannya adalah karena setara dengan posisinya di bidang pekerjaan.

Hal tersebut dapat dilihat dari wawancara dengan responden yang merupakan kepala cabang sebuah perusahaan penjualan, namun secara finansial bergaji UMP Jakarta (2,2 juta) :

"yaah..., gapapa lah (tidak apa-apalah). Mahalmahal kan biar ada (per)beda(an) dengan orang lain. Pekerjaan kan bagus, mesti beda dengan anak buah. Meski kadang penghasilan anak buah lebih baik, tetap harus beda dengan anak buah"

Wawancara tersebut dapat menjelaskan bahwa status tinggi dalam sebuah pekerjaan yang menunjukkan pada prestise dan kewenangan yang lebih baik dan besar, dapat membuat individu mengejar simbol status yang tinggi pula (misalnya pemakaman mewah).

3. Faktor Pendapatan. Berdasar analisis data, faktor pendapatan memiliki signifikansi sebesar 0.159 . Dengan nilai signifikansi $0.159>0.05$, maka $\mathrm{Ha}_{4}$ ditolak, yaitu faktor pendapatan tidak memberi pengaruh yang signifikan pada persepsi, artinya tinggi rendahnya pendapatan tidak memiliki pengaruh terhadap persepsi responden mengenai pemakaman mewah. Pendapatan yang tinggi ataupun rendah tidak berpengaruh pada motif, kebutuhan, dan harapan mereka akan pemakaman berharga fantastis tersebut. 


\section{PENUTUP}

\section{Kesimpulan}

Berdasarkan analisis data pada bab sebelumnya, maka dapat ditarik kesimpulan :

1. Status sosial ekonomi (SSE) yang terdiri dari pendidikan, pekerjaan, dan pendapatan secara bersama- sama memiliki pengaruh yang sangat signifikan terhadap persepsi responden mengenai pemakaman mewah

2. Jika dilakukan analisis lebih jauh, faktor yang paling berpengaruh secara signifikan adalah pekerjaan, sedangkan faktor pendidikan dan pendapatan tidak memiliki pengaruh yang signifikan.

3. Dapat ditarik kesimpulan juga, nampaknya tinggi rendahnya status pekerjaan menjadi lebih penting bagi responden terkait kepemilikan makam mewah. Hal ini agaknya berkaitan dengan simbol status yang mengiringi kepemilikan pemakamam mewah. Pendidikan tinggi tidak memiliki pengaruh signifikan terhadap persepsi para responden. Pendapatan yang tinggi juga tidak memiliki pengaruh signifikan pada persepsi mereka terhadap pemakaman mewah.

4. Harga makam mewah yang relatif sangat tinggi bagi masyarakat Indonesia mestinya berkaitan dengan mau /tidaknya seseorang untuk membelinya. Ternyata dalam riset ini justru faktor pekerjaan yang memiliki pengaruh lebih signifikan.

5. Riset ini belum memenuhi prinsip representativeness, jadi tidak dapat melakukan generalisasi empiris kepada seluruh masyarakat Jabodetabek.

\section{Saran}

Berdasar hasil riset dan kesimpulan, maka tim memberikan sejumlah saran. Riset ini masih terbatas pada persepsi, dan belum masuk terlalu dalam pada aspek-aspek psikologis lainnya, seperti kecenderungan berperilaku (intensi). Riset selanjutnya dapat masuk ke hal tersebut. Pemakaman mewah dan mahal pada prinsipnya tidak sesuai dengan ajaran Islam, karena Islam melarang bermewah-mewahan. Terkait hal ini, MUI telah mengeluarkan Fatwa no 09 pada 20 Februari 2014, tentang haramnya pemakaman mewah dan mahal. Meski demikian adanya layanan pemakaman mewah untuk umat lain tentu tidak dilarang. Dalam Al Quran, Surat Al-Kafiruun, dinyatakan : lakum diinukum waliyadiin (untukmu agamamu, untukku agamaku). Berdasar hal ini dapat dimaknai, siapapun di luar umat Islam sahsah saja tetap memilih pemakaman mewah tersebut, dan dapat menjadi responden dalam penelitian selanjutnya.

Terkait fatwa MUI tersebut, dapat menimbulkan pertanyaan baru, bagaimana dengan umat Islam yang sudah terlanjur membeli pemakaman mewah dan mahal? Perlu adanya kajian lebih dalam terkait hal tersebut. Supaya lebih menarik, dapat menggunakan Teori Tindakan Berencana (Planned Behavior Theory), sehingga dapat menjelaskan alasan-alasan psikologis responden untuk membeli pemakaman mewah dan mahal, dan sebaliknya. Jika terlaksana, maka riset ini akan lebih bermanfaat tidak hanya untuk menggambarkan fenomena dan dinamika yang terjadi dalam masyarakat, tetapi juga bermanfaat bagi instansi swasta yang mengelola pemakaman mewah.

Berhubung penarikan sampel dalam riset ini dilakukan secara accidental, belum representatif, sehingga sangat terbuka peluang bahwa SSE responden bisa saja menumpuk di salah satu strata, dan itu terjadi di riset ini. Pengulangan riset ini sangat disarankan dengan menggunakan metode sampling yang lain.

\section{DAFTAR PUSTAKA}

[1] "www.mediaindonesia.com," [Online]. Available: http://www.mediaindonesia.com/read/2011/10/04 /265423/37/5/Yang-Bener-Biaya-Pemakamanhanya-Rp100-Ribu. [Accessed 23 January 2012].

[2] "www.kompas.com," [Online]. Available: http://regional.kompas.com/read/2011/10/05/092 25659/Biaya.Pemakaman.di.DKI.Tak.Lebihi.Rp. 100.000 . [Accessed 2012 Januari 2012].

[3] "http://amg.alazhar-indonesia.com/," [Online]. [Accessed 30 April 2014].

[4] "www.detiknews.com," [Online]. [Accessed 30 April 2014].

[5] "www.jakarta.go.id," [Online]. [Accessed 30 April 2014].

[6] "www.hukumonline.com," [Online]. [Accessed 30 April 2014].

[7] "www.bps.go.id," [Online]. [Accessed 30 April 2014].

[8] "http://www.antaranews.com," [Online]. [Accessed 30 April 2014].

[9] S. Soekanto, " Sosiologi Suatu Pengantar," Jakarta, , Rajawali Press., 2001.

[10] L. A. King, "Psikologi Umum, Sebuah Pandangan Apresiatif (terj)," Jakarta,, . Penerbit 
Salemba Humanika, , 2007.

[11] C. J.P, "Kamus Lengkap Psikologi (terj)," Jakarta, Raja Grafindo Perkasa, 2009.

[12] S. Robbins, "Essentials of Organizational Behavior 7th Edition," New Jersey, Prentice Hall, 2002, p. 23.

[13] Solso, RL, Maclin, OH \& Maclin MK, "Psikologi Kognitif edisi ke delapan," Jakarta, Erlangga, 2008.

[14] J. Rakhmat, "Psikologi Komunikasi," Bandung, Remaja Rosda Karya, 2001, p. 51.

[15] B. Walgito, "Pengantar Psikologi Umum.," Yogyakarta, Andi. , 2004, p. 90.

[16] K. Sunarto, "Pengantar Sosiologi Edisi Kedua," Jakarta, Lembaga Penerbit FE-UI , 2000.

[17] R. M. Lawang., "Pengantar Sosiologi. Buku Materi Pokok.," Jakarta, Pusat Penerbitan Universitas Terbuka, 2004.

[18] Yulisanti.A.I, "Status Sosial Ekonomi dan Prilaku Konsumtif Kelas Menengah Baru," APMD, Yogyakarta, 2000.

[19] W. Lestarini, "Pengaruh Status Sosial Ekonomi terhadap Pemilihan Moda Transportasi untuk Perjalanan kerja (Studi Kasus Karyawan PT.SSSWI Kabupaten Wonosobo)," Universitas Diponegoro, Semarang, 2007.

[20] "www.jakarta.go.id," [Online]. [Accessed 30 April 2014].

[21] "www.bps.go.id," [Online].
[22] F. K. Halifat, "Pengaruh Status Sosial Ekonomi Orang Tua terhadap Motivasi Belajar Siswa kelas XI di SMK Negeri 1 Limboto Kabupaten Gorontalo," Universitas Negeri Gorontalo, Gorontalo, 2014.

[23] M. Rahmatullah, "Bisnis Pemakaman dalam Perspektif Islam. Studi Komparatif antara TPU Pondok Gede dan TPU Pondok Rangon," UIN Syahid, Jakarta, 2011.

[24] "www.mui.or.id," [Online]. Available: http://mui.or.id/wp-content/uploads/2014/05/No.09-Jual-Beli-Tanah-utk-Kuburan-dan-BisnisLahan-Kuburan-Mewah.pdf. [Accessed 30 April 2014].

[25] S. \&. J. D. Vanderstoep, Research Methodes for Every day Life. Blending Qualitative and Quantitatif Approaches, San Fransisco: Jossey Bass, 2009.

[26] M. \&. E. S. Singarimbun, Metode Penelitian Survey, Jakarta: LP3ES, 1995.

[27] S. Nasution, Metode Research (Penelitian Ilmiah), Jakarta: Bumi Aksara, 2000.

[28] [Online]. Available: www.hukumonline.com. [Accessed 30 April 2014].

[29] "http://www.al-azhar.ac.id," [Online]. [Accessed 30 April 2014]. 


\section{Lampiran 1}

Tabel 1. Matriks SSE

\begin{tabular}{|c|c|c|c|}
\hline Strata & Bawah & Menengah & Atas \\
\hline Pendidikan & $\begin{array}{l}\text { Tdk sekolah - } \\
\text { lulus SD/ sederajat }\end{array}$ & $\begin{array}{l}\text { SMP- } \\
\text { Lulus SMA/sederajat }\end{array}$ & Perguruan Tinggi \\
\hline Pekerjaan & $\begin{array}{l}\text { Petani, buruh, } \\
\text { operator bengkel }\end{array}$ & $\begin{array}{l}\text { Penjualan/bidang jasa } \\
\text { lainnya }\end{array}$ & $\begin{array}{l}\text { Tenaga ahli, } \\
\text { profesional } \\
\text { (sepertiDokter, } \\
\text { Pengacara, guru } \\
\text { dosen), pegawai di } \\
\text { kantor pemerintah } \\
\text { atau swasta }\end{array}$ \\
\hline Pendapatan & Rp. $<2.200 .000$ & $\begin{array}{l}\text { Rp. 2.300.000 - } \\
5.000 .000\end{array}$ & > Rp.5.000.000 \\
\hline
\end{tabular}

\section{Lampiran 2}

Status Sosial Ekonomi (SSE)

1. Pendidikan

2. Pekerjaan

3. Pendapatan

\section{Persepsi terhadap pemakaman mewah}

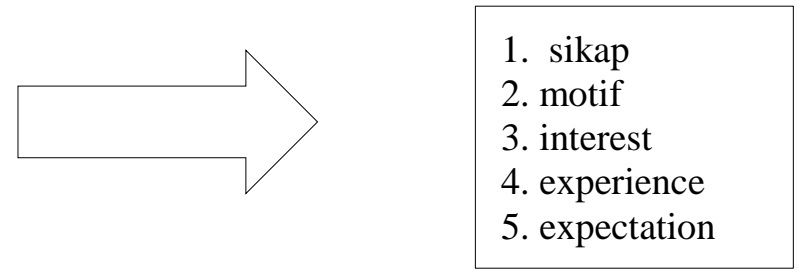

Gambar 1. Kerangka Berpikir 
Lampiran 3 : Blue print item

Tabel 2. Blue print untuk variabel persepsi

\begin{tabular}{|c|c|c|c|}
\hline NO & $\begin{array}{c}\text { Faktor-faktor persepsi } \\
\text { (Robin, 2002) }\end{array}$ & Indikator & Nomor Aitem \\
\hline 1 & Sikap (attitude), & $\begin{array}{l}\text { - pernyataan evaluatif, } \\
\text { - penilaian terhadap suatu target } \\
\text { persepsi }\end{array}$ & $\begin{array}{l}13,14.15,16,18,19, \\
20,21,23,24,25,26, \\
27\end{array}$ \\
\hline 2 & Motif (motive), & $\begin{array}{l}\text { suatu keinginan atau kebutuhan } \\
\text { seseorang terkait target persepsi }\end{array}$ & $3,6,7,8,12,17,22$ \\
\hline 3 & Interest, & $\begin{array}{l}\text { sesuatu yang sangat diperhatikan } \\
\text { seseorang dari suatu target } \\
\text { persepsi } \\
\text { (dapat dipengaruhi oleh } \\
\text { pengalaman, atau latar belakang } \\
\text { orang tersebut) }\end{array}$ & $1,2,4,5,9,10,11$ \\
\hline 4 & Experience, & $\begin{array}{l}\text { Pengalaman yang terkait dengan } \\
\text { target persepsi }\end{array}$ & $28,29,30,31,32$ \\
\hline 5 & Expectation & $\begin{array}{l}\text { harapan-harapan (pengharapan) } \\
\text { seseorang terhadap target persepsi } \\
\text { yang dapat mempengaruhi } \\
\text { persepsinya }\end{array}$ & $\begin{array}{l}33,34,35,36,37,39 \text {, } \\
39 .\end{array}$ \\
\hline
\end{tabular}

Tabel 3. Blue print untuk variabel Status Sosial Ekonomi (SSE)

\begin{tabular}{|c|c|c|c|c|}
\hline $\begin{array}{ll} & \text { Strata } \\
\text { SSE } & \end{array}$ & Bawah & Menengah & Atas & Nomor Aitem \\
\hline Pendidikan & $\begin{array}{l}\text { Tdk sekolah - } \\
\text { lulus } \mathrm{SD} / \text { sederajat }\end{array}$ & $\begin{array}{l}\text { SMP- } \\
\text { Lulus SMA/sederajat }\end{array}$ & Perguruan Tinggi & 3 \\
\hline Pekerjaan & $\begin{array}{l}\text { Petani, buruh, } \\
\text { operator bengkel }\end{array}$ & $\begin{array}{l}\text { Penjualan/bidang jasa } \\
\text { lainnya }\end{array}$ & $\begin{array}{l}\text { Tenaga ahli, } \\
\text { profesional (seperti } \\
\text { Dokter, Pengacara, } \\
\text { guru, dosen, } \\
\text { akuntan), pegawai } \\
\text { di kantor } \\
\text { pemerintah atau } \\
\text { swasta }\end{array}$ & 4 \\
\hline Pendapatan & Rp. $<2.200 .000$ & $\begin{array}{l}\text { Rp. } 2.300 .000- \\
11.000 .000\end{array}$ & > Rp.11.000.000 & 5 \\
\hline
\end{tabular}




\section{Lampiran 4}

Tabel 10. Pengaruh IV terhadap DV

Sumber : data primer, 2014

\begin{tabular}{|c|c|c|c|c|c|c|c|c|c|c|}
\hline \multicolumn{11}{|c|}{ Model Summary ${ }^{b}$} \\
\hline \multirow[b]{2}{*}{ Model } & \multirow[b]{2}{*}{$\mathrm{R}$} & \multirow[b]{2}{*}{ R Square } & \multirow[b]{2}{*}{$\begin{array}{l}\text { Adjusted R } \\
\text { Square }\end{array}$} & \multirow[b]{2}{*}{$\begin{array}{l}\text { Std. Error of } \\
\text { the Estimate }\end{array}$} & \multicolumn{5}{|c|}{ Change Statistics } & \multirow[b]{2}{*}{$\begin{array}{l}\text { Durbin- } \\
\text { Watson }\end{array}$} \\
\hline & & & & & $\begin{array}{l}\text { R Square } \\
\text { Change }\end{array}$ & F Change & df1 & $\mathrm{df} 2$ & Sig. F Change & \\
\hline
\end{tabular}

a. Predictors: (Constant), Pendapatan, Pekerjaan, Pendidikan

b. Dependent Variable: Persepsi

Tabel 11. Anova

Sumber : data primer 2014

ANOVA $^{b}$

\begin{tabular}{|ll|r|r|r|r|r|}
\hline \multicolumn{1}{|c|}{} & $\begin{array}{c}\text { Sum of } \\
\text { Squares }\end{array}$ & df & Mean Square & F & Sig. \\
\hline 1 & Regression & 2018.586 & 3 & 672.862 & 6.237 & $.001^{\text {a }}$ \\
& Residual & 6364.684 & 59 & 107.876 & & \\
Total & 8383.270 & 62 & & & \\
\hline
\end{tabular}

a. Predictors: (Constant), Pendapatan, Pekerjaan, Pendidikan

b. Dependent Variable: Persepsi

Tabel 12. Koefisien Regresi

sumber : data primer 2014

Coefficients $^{\mathrm{a}}$

\begin{tabular}{|c|c|c|c|c|c|c|c|c|c|c|c|}
\hline \multirow{2}{*}{\multicolumn{2}{|c|}{ Model }} & \multicolumn{2}{|c|}{ Unstandardized Coefficients } & \multirow{2}{*}{$\begin{array}{c}\begin{array}{c}\text { Standardized } \\
\text { Coefficients }\end{array} \\
\text { Beta }\end{array}$} & \multirow[b]{2}{*}{$t$} & \multirow[b]{2}{*}{ Sig. } & \multicolumn{3}{|c|}{ Correlations } & \multicolumn{2}{|c|}{ Collinearity Statistics } \\
\hline & & $\mathrm{B}$ & Std. Error & & & & Zero-order & Partial & Part & Tolerance & VIF \\
\hline \multirow[t]{4}{*}{1} & (Constant) & 99.591 & 7.420 & & 13.422 & .000 & & & & & \\
\hline & Pendidikan & -.046 & 1.564 & -.004 & -.029 & .977 & .264 & -.004 & -.003 & .705 & 1.419 \\
\hline & Pekerjaan & 5.936 & 1.684 & .472 & 3.525 & .001 & .462 & .417 & .400 & .717 & 1.395 \\
\hline & Pendapatan & 1.581 & 1.109 & .165 & 1.426 & .159 & .142 & .183 & .162 & .961 & 1.040 \\
\hline
\end{tabular}

a. Dependent Variable: Persepsi 